\title{
Beyond Business Ethics: An Agenda for the Trustworthy Teachers and Practitioners of Business
}

\author{
Ann Congleton
}

Received: 8 July 2012/ Accepted: 3 December 2012/Published online: 24 January 2013

(C) Springer Science+Business Media Dordrecht 2013

\begin{abstract}
Societies need markets, so just as trustworthy professionals are needed in fields such as healthcare, law and education, modern societies need trustworthy market managers, including corporate officers and directors. But in its screening of candidates, U.S. corporate business has lagged behind fields such as medicine and law, which in the nineteenth century addressed their need for screening by upgrading professional education and establishing licensing of individual practitioners. Corporate business, by contrast, has been too tolerant of problematic executives, particularly executives of a type shown by recent research in psychology to exhibit a set of personality traits including below average concern about bad effects of their actions on other people. Over-representation of this problematic type has cost corporate business the trust and respect it could earn by resting fully on a time-honored alternative foundation already espoused by many trustworthy teachers and practitioners of business. Society needs these trustworthy people of business to work together to establish screening of candidates for high level corporate positions by upgrading MBA education and establishing licensing for these positions. For reasons again based on current findings in psychology, screening candidates for the MBA could be significantly strengthened by requiring historical studies, particularly history of the corporate legal structure in the U.S. and history of the MBA itself. Upgrading the MBA and establishing correlated licensing could open the way toward corrections in the legal form of the corporation to bring it into line with hospitals, law courts and universities as places where responsible professionals pursue their callings on behalf of society.
\end{abstract}

A. Congleton $(\square)$

Wellesley College, Wellesley, MA, USA

e-mail: aconglet@wellesley.edu
Keywords Caveat emptor - Corporate structure · Dark triad - Education - History - Licensing - MBA . Personality $\cdot$ Stewardship $\cdot$ Temperament

\section{Introduction}

Someone who walked onto a used car lot and encountered a sign saying "Let the buyer beware"-the old caveat emptor - might consider the sign just unusually candid. But someone who walked into a doctor's office and encountered "Let the patient beware" would presumably flee. In the United States today, people can ordinarily assume that healthcare professionals are generally committed to seeking the well-being of patients. But medical quacks were a significant problem in the nineteenth century until the trustworthy members of the medical profession marginalized quacks by upgrading medical education and establishing licensing. The American Association of Medical Colleges, founded in 1876, stated as a commitment that "medical schools and teaching hospitals continually earn the trust and support of the public for their special missions." The National Board of Medical Examiners was founded in 1915.

Similarly, trustworthy lawyers of the nineteenth century reformed legal training and established licensing to deal with a comparable problem of charlatans injuring their profession. The American Bar Association was founded in 1878 "To serve equally our members, our profession and the public by defending liberty and delivering justice as the national representative of the legal profession." The National Conference of Bar Examiners was established in 1931.

Medicine and law are in need of further reform today to screen out members who become focused on wealth and 
status in ways that damage their attention to the well-being of patients and clients. But corporate business has yet to take even the steps taken by medicine and law in the nineteenth century, even though the need for reform in corporate business has been underscored by the economic collapse of 2008, quite possibly the largest display of caveat emptor behavior in history, seriously damaging millions of people. Moreover, caveat emptor practices in corporate business have contributed significantly to declines in trustworthiness in medicine and law.

As details of the economic collapse of 2008 have emerged, a striking feature has been the failure of executives who contributed to the collapse to acknowledge responsibility beyond the occasional token "sorry," even when they have been asked directly in settings such as Congressional hearings. ${ }^{1}$ Instead we are seeing continuation of corporate resistance to regulation, of the huge gap between executive and worker pay, of resistance to an equitable tax structure, and of indifference to public goods such as environmental protection, healthcare, and good schools for all children.

In this situation, the U.S. needs its trustworthy people of business, who are clearly the great majority, to take active leadership of their field and work to protect it and their society from caveat emptor executives. Leadership should no longer be left to business organizations with very large lobbying funds who have shown themselves to be part of the problem rather than of the solution. These organizations include the U.S. Chamber of Commerce, the Business Roundtable, the Financial Services Roundtable, and the American Legislative Exchange Council (ALEC).

In proposing to today's trustworthy people of business an agenda for marginalizing caveat emptor, this essay has three parts. Part I will identify and characterize two major sources of caveat emptor thinking in corporate business. Part II will describe a time-honored alternative to caveat emptor that already guides trustworthy business today. Part III will recommend that today's trustworthy people of business reform their field as was done by the trustworthy doctors and lawyers of the nineteenth century by upgrading business education in a particular way that would help screen out caveat emptor candidates and by establishing correlated licensing of high level corporate executives, both managers and directors.

\section{Two Sources of Caveat Emptor in Corporate Business}

The first of the two sources of caveat emptor in corporate business to be discussed here is a psychological one, namely a problematic subpopulation of the business

\footnotetext{
${ }^{1}$ See, for example, Charles Ferguson's documentary film about the 2008 collapse, Inside Job.
}

community that has been recognized since antiquity but that can be better understood today in the light of recent advances in psychology. The second source is a logical one, a particular idea too frequently found among these problematic executives.

\section{The Psychology of Caveat Emptor: Temperament and Personality}

Recent research in psychology has delineated a personality type for which caveat emptor is likely to be congenial. This personality is not a clinical disorder, although it has similarities to the clinical disorder psychopathy, which has been found to be more common among corporate executives than among, say, social workers or teachers. ${ }^{2}$ Because the personality type considered here is not a clinical disorder, executives of this type seem even more likely than psychopaths to be able to reach high levels in corporations.

\footnotetext{
${ }^{2}$ An excellent access point for the current scholarly literature on executive psychopaths is Clive R. Boddy's 2011 article "The Corporate Psychopaths Theory of the Global Financial Crisis." [Boddy 2011] Boddy notes in this article that although "corporate psychopaths are... poorly organized managers who adversely affect productivity and have a negative impact on many different areas of organizational effectiveness," it has also been "shown that psychopaths are... to be found at greater levels of incidence at senior levels of organizations than they are at junior levels.... There is also some evidence that they may tend to join some types of organizations rather than others," including large financial organizations.

Boddy offers a very interesting theory to account for this greater incidence, namely "that changes in the way people are employed have facilitated the rise of Corporate Psychopaths to senior positions." Boddy writes that
}

Prior to the last third of the twentieth century large corporations were relatively stable, slow to change and the idea of a job for life was evident, with employees gradually rising through the corporate ranks until a position was reached beyond which they were not qualified by education, intellect or ability to go. In such a stable, slowly changing environment employees would get to know each other very well and Corporate Psychopaths would be noticeable and identified as undesirable managers.... and their rise would therefore be blocked.

The World Health Organization's International Statistical Classification of Diseases and Related Health Problems defines its counterpart of psychopathy, which it calls dissocial personality disorder, by a list including the following items especially relevant to discussion of caveat emptor (World Health Organization 1990):

- "Callous unconcern for the feelings of others and lack of the capacity for empathy;

- Incapacity to experience guilt and to profit from experience, particularly punishment;

- Markedly prone to blame others or to offer plausible rationalizations for the behavior bringing the subject into conflict;

- Gross and persistent attitude of irresponsibility and disregard for social norms, rules, and obligations." 
A number of discussions of this subclinical personality are formulated in terms of an influential theory of adult personality traits, the "five factor model" (FFM). The following summary of the five factors is offered in the 2001 article "Effects of Personality on Executive Career Success in the United States and Europe: (Boudreau et al. 2001). ${ }^{3}$

Consensus is emerging that a five-factor model of personality, often termed the "Big Five" (Goldberg 1990), can be used to describe the many salient aspects of personality.... Evidence indicates that the Big Five are fairly heritable and stable over time (Costa and McCrae 1988; Digman 1989), although the environment undoubtedly plays a role.

The dimensions composing the five-factor model are neuroticism, extroversion, openness to experience, agreeableness, and conscientiousness. Neuroticism represents the tendency to... experience negative affect such as anxiety, insecurity, and hostility. Extroversion represents the tendency to be sociable, assertive, and experience positive affect such as energy, zeal, and excitement. Openness is the disposition to be imaginative, unconventional, and autonomous. Agreeableness is the tendency to be trusting, compliant, caring, and gentle. Conscientiousness comprises two related facets, achievement and dependability, and has been found to be the major component of integrity (Hogan and Ones 1997).

The FFM has been used by Nigel Nicholson, Emma Soane, Mark Fenton-O'Creevy and Paul Willman to characterize a type of "successful" executive as follows:

high extraversion (especially sensation seeking) and openness supply the motivational force for risk taking; low neuroticism and agreeableness supply the insulation against guilt or anxiety about negative consequences, and low conscientiousness makes it easier to cross [i.e. transgress] the cognitive barriers of... control, deliberation and conformity (Nicholson et al. 2005).

Earlier in their article these authors write that

A clear Big Five pattern emerges for overall risk propensity, combining high extraversion and openness with low neuroticism, agreeableness, and conscientiousness. At the subscale level, [extroversion as] stimulation-seeking surfaces as a key important component of risk propensity.... Following [Hans] Eysenck's theory of extraversion as a generalized need for stimulation, the extraversion scale $(E)$ is expected to follow the pattern predicted... for

\footnotetext{
3 Another sketch of the five and a brief history of the FFM are offered by Kowert et al. (1997).
}

sensation-seeking.... Openness to experience $(\mathrm{O})$ can be seen as a cognitive stimulus for risk seekingacceptance of experimentation, tolerance of uncertainty, change and innovation.... Conversely, conscientiousness (C), which can be summarized as a desire for achievement under conditions of conformity and control, is antithetical to these qualities and can be predicted to be inversely related to risk-propensity.... The literature also suggests that consistent risk-takers require resilience..., which would suggest that they should also score low in emotional sensitivity, implicating the neuroticism $(\mathrm{N})$ dimension of personality. The same logic could be applied to agreeableness (A), the tough to tender-mindedness dimension. Robust self-interest, and a lack of concern for the consequences to others of one's risk taking, could help to underpin the risk-taker.

Related findings come from psychological research on innate qualities in infants and children, called qualities of "temperament" to distinguish them from qualities gained from experience that combine with innate qualities to form what psychologists label "personality." Since the FFM qualities have been found to be "fairly heritable," i.e., to have innate elements, people cannot be simply "talked out" of these qualities. Therefore, while society needs to offer what psychologists call "prosocial" occupations for all adults, it is especially important to offer prosocial occupations for those who show the personality described above in terms of the FFM as low N, A, and C combined with high $\mathrm{E}$ and $\mathrm{O}$. We shall see that writers as diverse as Plato and William James have discussed war as being attractive to people who seem to show a similar personality.

The idea of innate qualities has often been resisted in the Anglo-American egalitarian tradition, which rests on foundations that include John Locke's seventeenth-century restatement of Aristotle's claim that every human mind starts off as "a blank slate," a tabula rasa. This tradition therefore tends to view personality as formed by experience alone, entirely by "nurture" as contrasted to "nature." However, commitment to the equality of opportunity and rights fundamental to democracy does not require that all infants start off alike. For example, society benefits from the fact that some children are born with special gifts in the arts. Society does not need to know which infants and toddlers have these innate potentials. Society only needs to keep in mind that if it wants the insight and riches the arts bring, it needs to provide pathways for artistic development, pathways open to all children who may wish to try them. The same is true for all other innate gifts that can benefit society: society does not need to label individual children, but it does need to provide pathways. 
In research on innate temperament particularly relevant to efforts to minimize caveat emptor, psychologist Jerome Kagan and others have found that if four-month old infants are suddenly presented with something unfamiliar and unexpected, such as a clown, their responses tend to fall into four groups. Some infants will cry and also wave their arms and legs, some will cry but not move so much, some will move a lot but not cry so much, and some will not do much of either. (e.g., Kagan 1997) Research has shown that each of these four patterns involves a different brain pattern.

To illuminate differences, research has focused on the two groups most different from each other, even though the majority of infants belong to the intermediate groups. The infants who both cry and wave their limbs are known as "high reactives," and the infants who do little of either are known as "low reactives." These differences at four months have been found to correlate significantly with differences among toddlers in such things as how much they do or do not tend to move away from their caregiver to explore a new environment, with the low reactives more likely to be the ones who go exploring. For these differences among toddlers, the terms "inhibited" and "uninhibited" are used as counterparts of "high reactive" and "low reactive", with the majority of children again between these two most contrasting groups. ${ }^{4}$ These early differences have been found to correlate significantly with behavioral and associated neurological patterns in adults. ${ }^{5}$

Research has found that the low reactive/uninhibited children are the most likely to develop into older children whose attention is externally oriented rather than reflective, who seek stimulation and enjoy risk, and who are more resistant to regulation and more likely to cheat. These children are significantly less likely than the high reactive infants/inhibited toddlers to be "empathic" about others or aware of the effects of their actions on others. They are more likely to act impulsively and to transfer blame for their errors to someone else or to some aspect of their environment. Interestingly, these low reactive/uninhibited children tend to exhibit more frequent smiling and are more

\footnotetext{
${ }^{4}$ Noted researchers Mary Rothbart and John E. Bates write that "a child easily overwhelmed by stimulation [a high reactive child] will try to keep things quiet, whereas a child who requires a high level of stimulation for pleasure [a low reactive child] will attempt to keep things exciting." (Rothbart and bates 1998)

5 E.g., Dr. Carl E. Schwartz and colleagues at Massachusetts General Hospital reported in Archives of General Psychiatry, January, 2010, that
}

Adults with a low reactive infant temperament, compared with those categorized as high reactive, showed greater thickness in left orbitofrontal cortex. Subjects categorized as high reactive in infancy, compared with those previously categorized as low reactive, showed greater thickness in the right ventromedial prefrontal cortex. (Schwartz et al. 2010). likely than the high reactive/inhibited children to seek to belong to a team or group of similar children.

Although Kagan's focus in this research has been on innate temperament, he has always also affirmed the great importance of nurture. He writes as follows about the low reactive/uninhibited children:

Individuals who belong to this temperamental category who are raised in affectionate homes that encourage accomplishment and are fortunate enough to attend good schools are likely to become adults who enjoy high risk vocations, such as politics, investment, and trial law. But the same children are at risk for a criminal career if they grow up in ... homes in which aggressive behavior is incompletely socialized and their neighborhoods contain temptations for delinquent acts. Thus, the same temperamental (i.e., innate) bias can lead to different [adult] personalities when development occurs in distinctive settings (Kagan 2008).

The high reactive/inhibited children, by contrast, are at greater risk of becoming withdrawn and depressed adults if they grow up in an environment that does not protect them from being overwhelmed and thereby prevented from developing into the perceptive, empathic adults so many of them have the potential to become. Thus, it is important for society to provide a wide range of pathways to enable children of the whole range of temperaments and talents to develop into prosocial adults. However, it is from the low reactive/uninhibited children that caveat emptor adults are most likely to emerge, and so they are the focus here.

In thinking about prosocial outcomes for these children, researchers have developed a useful distinction between "reactive" aggression, which is "an impulsive and hostile act displayed in response to a perceived threat or provocation," and "proactive" aggression, which is "a nonprovoked aversive means of influencing another." High reactive/inhibited children are more likely to exhibit only reactive aggression, while low reactive/uninhibited children are the ones likely to engage in proactive aggression as well (Poulin and Michel 2000). These differences have been found to relate to the development of conscience in children, with the development more difficult for proactively aggressive children, who tend to be lower in empathy for others and less aware of the impact of their actions on others. Proactively aggressive children also tend to be less responsive to punishment than inhibited, internalizing children, who may be even too responsive to punishment, becoming all the more withdrawn.

Just as high reactive/inhibited children benefit from being supportively encouraged to explore more freely, so it is important that limits be clearly set and maintained for low reactive/uninhibited children. But this limiting needs 
Table 1 Relative ratings on qualities of the children in Hawley's groups (Scale goes from $1=$ highest to $5=$ lowest)

\begin{tabular}{llllll}
\hline & Bistrategic & Coercive & Prosocial & Typical & Subordinate \\
\hline Self rating & 2 & & & & \\
$\quad$ Agreeableness & 1 & 4 & 1 & 3 & 5 \\
Aggression & 1 & 2 & 4 & 3 & 5 \\
Resource control & 1 & 2 & 2 & 4 & 5 \\
Cheating & 1 & 4 & 3 & 5 \\
Peer rating & 2 & & & & 5 \\
Perceived popularity & 1 & 2 & 1 & 4 & 5 \\
Aggression & 1 & 3 & 2 & 4 & 5 \\
Resource control & $17.5 \%$ & $17 \%$ & $15 \%$ & $35.5 \%$ & $15 \%=100 \%$ \\
Percent of all children & & & &
\end{tabular}

to be done in a way that affirms the child and works to draw the child into empathic relationships.

Since it is from among the uninhibited, excitementseeking, proactively aggressive, low-empathy risk takers that caveat emptor adults are more likely to emerge, it is helpful that they have been considered by researchers working from a variety of theoretical approaches. For example, an insightful study by Professor Patricia H. Hawley sorted a sample of 1,700 fifth to tenth grade children into five groups according to what she called their "control of resources" [Hawley 2003]. The groups were "Coercive controllers" (children who used proactive aggression to get what they sought and were "more concerned to get ahead than to get along"), "Prosocial controllers" (children who sought to achieve objectives through cooperative approaches and were "more concerned to get along than to get ahead"), "Bistrategic controllers" (children who used both aggression and cooperation), "Subordinates" (children who did not control and were more likely to be controlled), and the largest group, "Typicals" (children between the Controllers and the Subordinates). Table 1 is an abbreviated version of one of Hawley's tables, simplified to show only the rank order of the five groups of children.

Because Hawley is studying older children, we cannot know from her findings the balance of socialization and innate temperament involved in these figures. It should also be noted that all five groups of children include significant numbers of both boys and girls, although not in the same proportions. ${ }^{6}$

Hawley is particularly interested in the children she calls "Bistrategic," the children who are concerned both to "get along" and "get ahead" and who are the most relevant for understanding "successful" caveat emptor executives.

\footnotetext{
${ }^{6}$ This variation in gender balance among the five groups can be seen in the two charts below, which I have constructed from data in Hawley's article. After adjusting for the small difference between the total numbers of boys and of girls in the study, the charts work out as in Table 2
}

Table 2 Gender distribution (constructed from data included in Hawley's article)

A. Percent of boys and of girls belonging to each of the five types of controllers

\begin{tabular}{lll}
\hline & Boys & Girls \\
\hline Bistrategic & $20 \%$ & $15 \%$ \\
Coercive & 24 & 10 \\
Prosocial & 12 & 18 \\
Typical & 31 & 40 \\
Subordinate & 13 & 17 \\
Total & $100 \%$ & $100 \%$ \\
\hline
\end{tabular}

B. Percent of each of the five types made up of boys and of girls

\begin{tabular}{llll}
\hline & Boys & Girls & Total \\
\hline Bistrategic & $56 \%$ & $44 \%$ & $100 \%$ \\
Coercive & 71 & 29 & “ \\
Prosocial & 41 & 59 & “ \\
Typical & 43 & 57 & “ \\
Subordinate & 44 & 56 & “ \\
\hline
\end{tabular}

These Bistrategic children are perceived by both their peers and themselves as having the most control of resources, while being second to only the prosocial controllers in "likeability/agreeableness" and in "perceived popularity." Also, the Bistrategic children are considered by both their peers and themselves to be more agreeable and to have more control of resources than the Coercive children.

However, the Bistrategics share with the Coercives the top spot for self-rated cheating. In addition, the Bistrategics are ranked number one in aggression by both their peers and themselves, although Hawley reports that teachers see the Bistrategics as less aggressive than the Coercives. (Could it be that it is easier for a "Bistrategic" child to pull the wool over the eyes of a teacher than of a peer?)

A major question about Hawley's Bistrategics that is important for understanding the psychology of caveat emptor adults is whether there are actually two kinds of sociality: an instrumental, potentially exploitative "social 
savvy" or "shrewdness" found in the Bistrategic children and a more "empathic" sociality that makes the Prosocials number one in "perceived popularity." Could it be that it is a lack of either of these two types of sociality that reduces the "pure" Coercives to fourth in "Perceived popularity"? The subtitle of Hawley's article appears to recognize this difference between instrumental and empathic forms of sociality. Even though she finds much about the Bistrategic children that is positive, the fact that they rank themselves number one in both cheating and aggression, and are ranked number one in aggression by their peers, seems to be what leads Hawley to label them "Machiavellian" and to give her essay the subtitle "A case for the well-adapted Machiavellian."

Hawley's "Machiavellians" share that label with an adult personality type similar to what is here seen as the caveat emptor adult. A growing literature joins subclinical Machiavellianism, narcissism and psychopathy in what is called "The Dark Triad."

Obviously the above sketches of temperament and personality are not sufficient for identifying any particular individual as fitting these profiles or any others. But identifying individuals is unnecessary for recognizing that research in temperament and personality indicates that societies should expect that among their members will be a significant number who show Hawley's "bistrategic" pattern. Societies therefore needs to give attention to what prosocial activities can be provided for members of this type, as for all types, and what childhood experiences could be helpful in minimizing the production of caveat emptor adults.

Although current psychologists are casting important new light on differences in temperament and personality, they are certainly not the first to notice them. For example, both Plato and William James observed that some humans appear to be temperamentally drawn to war for its own sake. They are not thinking of the insane butchers who are regarded with horror as war "criminals," nor of people who reluctantly go to war to defend against attackers. They are thinking of people who like war for its excitement and riskiness. Since it is hard to imagine someone approving of war for its excitement without having considerable indifference to war's effects on others, i.e., without being low in empathy, these discussions by Plato and James cast light on the question of caveat emptor.

Plato presents as the main speaker of his Statesman an "Eleatic Stranger" who holds that one of the tasks of the true statesman will be to "weave together" like the warp

\footnotetext{
7 A good starting place for study of the "Dark Triad" is "The Dark Triad of personality: Narcissism, Machiavellianism, and psychopathy" by Paulhus and Williams in the Journal of Research in Personality in 2002.
}

and woof of cloth two naturally occurring types of citizens whose effects can be balanced by this weaving. The Eleatic Stranger says that without this balancing,

those who are too peaceful wind up as slaves, while those drawn to andreia [literally "manliness" but usually translated as "courage"] urge their countries to war because of their excessive desire for a warlike life." (Plato 1997a: Statesman 307-08) ${ }^{8}$

Similarly, William James, using the word "moral" in the now obsolete sense in which it served as a catchall for all inquiries not part of natural science, and writing in the time of Theodore Roosevelt's enthusiasm for war, gave in 1906 a talk entitled "The Moral Equivalent of War." (James 1906) In this talk, James endorses the view that some human qualities are innate, and that society therefore needs to provide constructive outlets for them. In particular, James wrote of the person who

inherits all the innate pugnacity and all the love of glory of his ancestors. Showing war's irrationality and horror is of no effect on him.... War is the strong life; it is life in extremis.

James further wrote that

The weakness of ... merely negative criticism is evident-pacifism makes no converts from the military party. The military party denies neither the bestiality nor the horror nor the expense; it only says that these things tell but half the story. It only says that war is worth them.... So long as antimilitarists propose... no moral equivalent of war,... so long they fail to realize the inwardness of the situation.... The duties, penalties, and sanctions pictured in the utopias they paint are all too weak and tame to touch the military minded.

The alternative James proposed for "the military minded" was organized national service. His proposal is seen by Jon Roland in his "Introduction" to James's essay as leading directly "to the depression-era Civilian Conservation Corps, to the Peace Corps, VISTA, and AmeriCorps." (Roland 2000) James wrote that

To coal and iron mines, to freight trains, to fishing fleets in December, .... to road building and tunnelmaking, to foundries and stoke-holes, and to the frames of skyscrapers, would... youth be drafted off... and ... come back into society with healthier sympathies and soberer ideas.... [U]ntil an equivalent

\footnotetext{
8 Statesman, 306-end. Plato notes the difference between these qualities in Book III of the Republic as well, although he there seems to see them as more combinable in single individuals than he does in the Statesman, generally considered to be a later dialog.
} 
is organized, I believe that war must have its way. But I have no serious doubt that the ordinary prides and shames of social man, once developed to a certain intensity, are capable of organizing such a moral equivalent as I have sketched.

James's examples would need revision to fit today's technology and would also need extension to higher ages to provide for citizens of this personality type throughout their working lives. In addition to developing prosocial occupations for these citizens, we need to make every effort to help all children, but especially low reactive/uninhibited children have the empathic relationships and other experiences needed to help them develop into prosocial adults.

\section{The Logical Root of Caveat emptor}

Keeping in mind this discussion of a psychological root of caveat emptor behavior, let us consider a logical root, an idea that is like the psychological root in being overrepresented in today's corporate business.

This logical root of caveat emptor is its suggestion that the relationship between seller and buyer is a kind of contest. This notion of contest is not accepted for professional relationships such as doctor and patient or teacher and student. However, particularly since World War II produced the upsurge in computers that was followed by an upsurge in game-thinking in many areas, the language of contest, especially games, has become particularly common in business. Let us look first at some examples and then at what thinking of business as a game can encourage and seem to justify in caveat emptor executives.

Perhaps the very ubiquity of the language of games in business today explains why it has not been sufficiently challenged. The legendary CEO of General Electric, Jack Welch, saw no need to give evidence for his assertion that "business is a game, and winning that game is a total blast." This claim opens his 2005 bestseller, Winning, whose dust jacket carries the following blurb from Tom Brokaw, then managing editor of the NBC Nightly News:

Reading Jack Welch's plain-language, high-energy book Winning is like getting the playbook of the Super Bowl champions before the game. It's a big head start on how to master the corporate game from the entry level to the corporate suites.

The language of corporate business as a game is particularly common in a genre of books like Welch's that are especially prominent in airport bookstores. Another of these "airport books" is The Game-Changer by the CEO of Procter and Gamble, A.G. Lafley, and Ram Charan (2008). It opens with a definition of "game-changer" as "a visionary strategist who alters the game his business plays or conceives an entirely new game." And there is Touchdown: Achieving Your Greatness on the Playing Field of Business (and Life) by Dr. Kevin Elko. (Elko 2009). Its dust jacket says that "Kevin's appeal in the sports world translates directly to the corporate arena."

These "airport books" are profitable for publishers, and many major presses today have business imprints alongside their cookbook and murder mystery imprints. The Harvard Business School Press told Publishers Weekly in March, 2000, that "We invest a lot of effort and resources selling our books into airport stores, because we want them exposed to the business travelers."

The language of business as a game can also be found in academic business writing. For example, "How Banks Played the Leverage Game" is the title of an essay by Stern School of Business Professors Acharya and Schnable in Restoring Financial Stability, a 2009 anthology about the 2008 economic collapse.

Thinking of business as a game can offer many attractions for a practitioner of caveat emptor. Let us consider the following four:

1. Regarding business as a game can provide a license to disregard economically vulnerable members of society.

2. Focusing on the goal of winning a game can divert attention from the question of whether the game should even exist.

3. Viewing business as a game connects it to team sports and war, activities that societies have long accepted.

4. Thinking of business as a game requires thinking of it as an activity organized by rules, since rules are needed to make determination of winners possible. But thinking in terms of rules can lead in some people to looking for ways rules can be "worked around," ways such as loopholing, rigging, and outright cheating.

How viewing business as a game can provide a license to disregard society's vulnerable members can be seen by looking at parallels between the business and sports sections of newspapers. When we turn to the sports pages to catch up on our favorite teams or athletes, we do not expect to find ourselves reading about the people who sweep the stadium or sleep on the sidewalks outside of it. The stadium sweepers and sidewalk sleepers are not part of the teams, nor are they ticket-buying fans who help finance the teams (and the marketers and bookmakers). The sweepers and sleepers are not even the losers. They are simply not part of the game at all, not people whom teams or sports page writers or readers need to think about when they think about their favorite sports.

Consideration of society's sweepers and sleepers is also simply absent from airport business books, an absence which is unsurprising if society's vulnerable are perceived as not relevant to the games with which airport books are 
concerned. ${ }^{9}$ The corporations and teams are just keeping their minds focused on the game, as players are expected to do.

Although consideration of the economically vulnerable is absent from the airport books, there is a popular view of poverty that gamesters can use in reply if their neglect of poverty is questioned, namely the view that the poor have brought poverty on themselves by being lazy and failing to better themselves in this land of opportunity. The spuriousness of this reply was shown by a report by the Economic Mobility Project of the Pew Charitable Trust in 2007, i.e., before the 2008 collapse, that found the U.S. much lower in economic mobility and much higher in income inequality than other advanced nations, specifically European countries and Canada. Commenting on the Pew and similar reports, Nobel Prize economist Paul Krugman has written that

Americans are much more likely than citizens of other nations to believe that they live in a meritocracy. But this self-image is a fantasy: ...America actually stands out as the advanced country in which it matters most who your parents were, the country in which those born on one of society's lower rungs have the least chance of climbing to the top or even to the middle (Krugman 2012).

A second attraction of viewing business as a game is that the questions of how to play and win the game are independent of the question of whether is it good for the game to exist at all. Thus, the question of how to play and win at poker is distinct from the question of whether it is a good idea to play poker at all. There is nothing in the rules and strategy of any game that forces its players to address the question of whether the game itself may be something society would be better off without. For example, society would be better off without the tobacco, predatory lending and fast food "games," all of which reflect in their executives and marketers what we may call a "willingness to harm." The kind of thinking required for deciding whether a game should exist at all can seem to a gamester an unwelcome and too difficult distraction from the kind of thinking required for skill and victory in the game.

A third attraction of thinking of business as a sport is the opportunity it offers for explicit and indeed celebrated competition. Competition between groups or teams or armies goes beyond competition within a group, the sort of individual competition that occurs when, e.g., violinists in

\footnotetext{
${ }^{9}$ I am not aware of any airport book which has had the hutzpah to promote the bottom-feeding business "games" which actually target the poor, games of actively exploiting them, of finding ways to siphon off what little money may come their way. The paycheck cashing racket is one that has received some public notice, and a concise introduction to this and other such rackets is provided by T. B. Edsall in his article "Is poverty a kind of Robbery?" (Edsall 2012).
}

an orchestra compete to become concertmaster. The competition among individuals that tends to be present in any group activity requires considerable diplomacy to handle gracefully, whereas the competition between teams can be thrilling in its overtness, its permission and even encouragement to "destroy" the opponent.

Team competition also creates bonds of "team spirit" among team members. These bonds have their counterpart, or perhaps their prime instance, in the ties that can lead a soldier to die for buddies in war.

An airport book based on similarities between war and corporate business is Business as War: Battling for Competitive Advantage, published in 2004 by Kenneth Allard, an Army colonel who became an MSNBC commentator on business and military affairs and a lecturer in Management at the University of Texas (Allard 2004). The dust jacket blurbs include the following:

"In war, they don't give out medals for second place.

In business as in war, you can't win without first sur-

viving. Increasingly, the business landscape looks more like a battlefield than a boardroom or shop floor. Written in a style that is 'pure Allard,' Business as War offers the hard-won wisdom from one warrior's world to another. Read, laugh, squirm, survive, and win!"

Scott A. Snook, Professor of Organizational Behavior, Harvard Business School

"In the post-9/11, post-Enron environment, Ken Allard's Ten Commandments of Military Leadership are directly applicable to today's business CEOs."

Tom Petrie, Vice-chairman of Merrill Lynch

The dust jacket of Business as War also reflects the way the business suit provides executives with a uniform analogous to those of soldiers and sports team members. On the back is a full-length photo of Colonel Allard wearing battle fatigues and standing feet apart with arms folded across his chest in classic drill sergeant pose. On the front is Mr. Allard in the same pose but now wearing the business suit. It has been interesting to watch leaders of the upstart electronics industry such as Steve Jobs and Bill Gates challenge the business suit. However they have not done nearly as much to promote departure from the suit as the media have done to narrow even the choice among suits, since dark suits are more flattering for today's camera lights and lenses. Business suits can, of course, vary enormously in price, but in a news photo these differences fade, and as U.S.-style corporate business has spread around the world, the media increasingly feature photos of international groups of executives and politicians almost all wearing the dark business suit, even when the group includes people from cultures whose leaders traditionally dress in flowing robes or other traditional garments. The 
relatively few women who appear in these photos are still trying to figure out what to wear as they enter the world of the business suit.

Sports teams and armies and corps of executives are similar not just in liking uniforms but also in ability to consider defeat of rivals a sufficient reason to exist, so that selling harmful products is acceptable if it can be a path to becoming a winner as measured by wealth and power. By contrast, music and theatre groups and small local businesses can thrive without any other such organizations around, because these organizations are energized by something other than conquest.

Thus in corporate business, the various "industries" can be thought of as leagues, and through the convenient measure provided by dollars, we can check the standings daily through the stock and bond price listings that the New York Times for decades called the "Market Scoreboard." The corporations as competing teams take to the field, and we look on, placing our bets via the stock and bond markets, exchanging opinions with other fans, or expressing them in our columns or blogs if we are the sort of business pundit who is a counterpart of sports writers.

A fourth attraction of viewing business as a game can be exploiting the possibilities of rules. Rules are necessary to games for determining winners, and in fact, any activity that has clear enough rules can be turned into a game and thus make winning a possible reason for participating. But although rules are needed to make a game and are generally respected by most participants, they can seem constraining to some participants, especially those who by temperament are relatively resistant to limits and low in the "conscientiousness" and "agreeableness" factors of the FFM. Three ways such players may deal with inconvenient rules are cheating, loopholing, and rigging.

Cheating has been found to be even more frequent among business students than among students in other fields. A 2006 study reported that while cheating was high in many graduate programs, it was highest among MBAs at $56 \%$ (McCabe 2006). This article also reported a 1997 survey of undergraduates which similarly found that while cheating was high among all undergraduates $(66 \%)$, it was highest among business majors (84\%).

A particularly blatant and well-documented manifestation of cheating in the context of the 2008 collapse has been the manipulation by bankers of the so-called LIBOR, the "London Interbank Offered Rate," a rate at which banks lend to one another. A spokesman of the U.S. Department of Justice stated that

Because mortgages, student loans, financial derivatives, and other financial products rely on LIBOR and EURIBOR [European Interbank Offered Rate] as reference rates, the manipulation of submissions used to calculate those rates can have significant negative effects on consumers and financial markets worldwide. $^{10}$

David Enrich, European banking editor for The Wall Street Journal, explained that the LIBOR

is arranged by a trade group of banks in London. Every day around lunchtime in London, about 16 banks submit to the British Bankers' Association data that is an estimate of how much it would cost those banks to borrow from each other. (Enrich 2012)

The "Statement of Facts" appended to the Justice Department's June, 2012, statement of its settlement with one of the major banks involved, Barclays, includes many illustrations of what bank employees were doing with the LIBOR. ${ }^{11}$ Here are two samples:

...on Monday, March 13, 2006, at approximately

7:48 a.m., Trader-1 wrote to Submitter-1:

“... [Clients] were screaming at me about an unchanged $3 \mathrm{~m}$ [onth] libor. As always, any help wd [would] be greatly appreciated. What do you think you'll go for $3 \mathrm{~m}$ [onth]?" Submitter-1 responded, "I am going 90 altho[ugh] 91 is what I should be posting." Trader-1 replied in part: "I agree with you and totally understand. Remember, when I retire and write a book about this business your name will be in golden letters...." Submitter-1 replied, "I would prefer this not be in any books!" Barclays's 3-month Dollar LIBOR submission on March 13, 2006 was $4.90 \%$...."

"We're getting killed on our $3 \mathrm{~m}$ [onth] resets, we need them to be up this week before we roll out of our positions. Consensus for $3 \mathrm{~m}$ today is $4.78-4.7825$, it would be amazing if we could go for 4.79 ...Really appreciate ur help mate." (ellipses in original). Submitter-2 responded, "Happy to help." Barclays's 3-month Dollar LIBOR submission on February 22, 2006 was $4.79 \%$."

Gretchen Morgenson, one of the most insightful and earliest analysts of the crash of 2008 , commented on the apparent tendency of the leaders of the banks involved to evade responsibility:

Manipulating the Libor is a big deal because it affects the cost of money for almost everyone.... One of the most revealing exchanges in the Barclays documents

\footnotetext{
$\overline{10}$ http://www.justice.gov/opa/pr/2012/June/12-crm-815.html Retrieved July 7, 2012.

11 http://www.justice.gov/opa/pr/2012/June/12-crm-815.html Retrieved July 7, 2012.
} 
came when a bank official tried to describe why Barclays's improper postings were not as problematic as those of other banks. "We're clean but we're dirtyclean, rather than clean-clean," an executive said in a phone conversation. Talk about defining deviancy down. "Dirty clean" versus "clean clean" pretty much sums up Wall Street's view of cheating. If everybody does it, nobody should be held accountable if caught.... Wall Street is pushing back, especially on the Commission's proposal that swap execution facilities provide market participants, before they buy or sell, with easily accessible prices on "a centralized electronic screen." The Commission's rule would eliminate the one-to-one dealings by telephone that are so lucrative to traders and so expensive to investors.(Mogenson 2012)

A way to escape the constraints of rules without actually cheating is to identify loopholes. Widespread tolerance for this may be illustrated by our approach to our taxes each April. If any of us (or H.R. Block) finds a loophole, it is ours to exploit for as long as it lasts. American multinationals, thanks to attorneys specializing in tax law, usually manage to pay only about half of the mandated $35 \%$ corporate tax rate, with GE, for example, paying only $7.4 \%$ in 2010 (Nocera 2011). Laws and regulations can offer gamesters and their lawyers the same exciting challenge that computer systems offer hackers: how to "outsmart" them.

Recognition of corporate loopholing as common practice is widespread enough for the cartoonist P.C. Vey to have played upon it in the New Yorker at the time Congress was debating the Dodd-Frank regulatory bill which became law in early 2010. It remains to be seen whether corporate lobbying will prevent Dodd-Frank from being given rules of application that give it actual strength: (Vey 2009).

Cheating and loopholing bring up the role of umpires, who are not needed in the arts but are needed in sports to decide whether a given action is within the rules and to penalize infractions. But there are ways for gamesters to get around umpires: they can be pressured or bribed or things can simply be done out of their view. Thus umpires can unintentionally contribute to violations simply by existing, since responsibility for the rules can then be shifted to them, freeing players to do whatever they can "get away with." Although it is true that the present economic crisis has spotlighted a pressing need to strengthen regulatory oversight, particularly the oversight of the financial industry weakened by federal government administrations from Reagan forward, it would be a mistake to forget that for gamesters, working around the umpire can be just another aspect of the game.

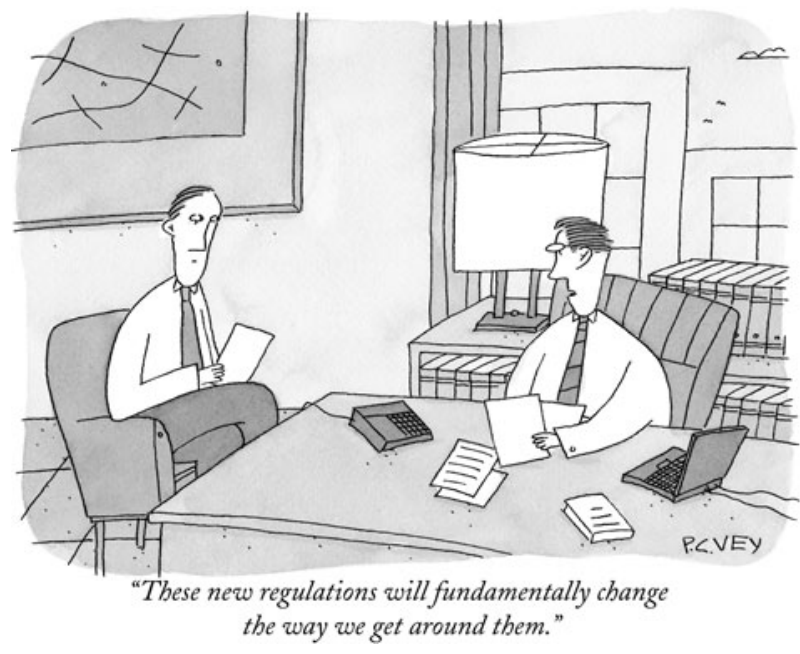

Fig. 1 Cartoon by P.C. Vey, New Yorker, March 9, 2009

In addition to cheating and loopholing, another way to deal with rules is to get the rule makers to rig them in one's favor. We will look later at the long history of rigging the law to benefit U.S. corporations, rigging which has mostly been done through the courts and legislatures, exploiting the fact that the general public usually does not follow court and legislative actions closely enough to focus upon and resist what is being done.

It should also be noted again that the rules that define a game do not address the question of whether it is good for that game to exist at all. Furthermore, game and war thinking in business cannot be dismissed as "just metaphors." Metaphors can shape our thinking in major ways even when we do not realize it, and metaphor can become reality. Thus, corporate competition is a game if enough practitioners (and spectators) see it that way.

In the light of these discussions of psychological and logical roots of caveat emptor gamesterism, we can ask ourselves what a nation might look like if too many positions of power in corporate and political and military structures came to be held by caveat emptor gamesters, call them CEGs, with their externalizing quest for excitement through risk and competition; their tendency to think any damage done by their game is due to circumstances or other people; their deficiency in empathy; and their disposition to disregard people they see as outside their game. Might not a nation with too many caveat emptor gamesters in positions of power look, alas, very much as the U.S. looks today?

If the U.S., and the world increasingly shaped by U.S. corporate business, are to extricate themselves from the dangers of caveat emptor gamesterism, the trustworthy people of business need to establish the MBA and 
corporate business on a foundation that makes corporate careers less attractive and accessible to caveat emptor gamesters, CEGs.

\section{An Alternative to Caveat Emptor Gamesterism as a Foundation for Business}

Fortunately, there already exists a foundation as prosocial for corporate business as health is for medicine and justice is for law. It goes back at least as far as Plato, and trustworthy business people today already espouse it. Contemporary language for this prosocial foundation is offered by Harvard Business School Professor Rakesh Khurana when he recommends that MBA students be educated to be "stewards of society's economic resources." (Khurana 2011) This goal of stewardship of society's economic resources will be clearer if we look at a pair of older expressions of it, beginning with a 1931 Yale Law Review article contrasting it explicitly to caveat emptor.

William Hamilton, a Professor of Law at Yale who assisted President Franklin Roosevelt in developing the New Deal, became concerned about the fate of consumers as burgeoning industrial technology generated more and more products whose quality could not be competently assessed by lay consumers, forcing consumers to place increased trust in manufacturers and sellers. In his 1931 article "The Ancient Maxim Caveat Emptor," Hamilton looked into the history of the phrase "caveat emptor" and reported that despite its being in Latin and despite ancient Rome's abundance of legal debate, he was unable to find any record of the phrase among the Romans or in Europe before the later Middle Ages. He noted that after the fall of Rome, trade gradually reemerged in Europe with the rise of traveling fairs and then of permanent market towns and eventually of cities, but that despite this evolution, it continued to be true that, in thirteenth-century language Hamilton cites from Thomas Aquinas, "rightful trade... served public necessity." (Hamilton 1931, p. 1137, drawing on Summa Theologica II.II. Q.LXXVII.Art. IV)

Hamilton writes that duping buyers was considered as injurious to the public order as other infractions such as assault or theft. Indeed,

the records attest the dominance of the idea of solidarity. The welfare of the collect is always given first position.... The devices in which greatest reliance was put were publicity and prevention. The deceitful maker and the dishonest vendor were paraded through the streets with their fraudulent wares, exposed in the stocks with their false products burned beneath their feet.... In the prevailing legal theory it was not so much the buyer who was injured as the commune. [p. 1152-1153]

Hamilton thinks that as towns arose, the phrase caveat emptor may have come into use to warn people not to get drawn into what we today call the "black market." He writes that in back streets,

away from the marts of organized trade were to be found the wayfaring palmer with his relics and trinkets, the peripatetic peddler with gew-gaws and ornaments, strangers here today and there tomorrow, wayfaring men of no place and without the law. [p. 1162]

In sum, Hamilton concludes that up through the Middle Ages the dominant view was that in commercial abuses "it was not so much the buyer who was injured as the commune" and that "the sense of the age, concerned to secure the common profit, had no reputable place for a notion of caveat emptor." [p. 1156]

The view of medieval commerce reported by Hamilton accords with the view that Plato has Socrates express in Book Two of the Republic when Socrates describes what he calls the "healthy city." [Plato Republic II. 369d-372e] The healthy city is very different from the "fevered" or "luxurious" city discussed in the remainder of the Republic, with its philosopher kings and queens as absolute rulers and its army to defend and extend its luxuries. ${ }^{12}$ In characterizing the "healthy" city, Socrates says that its people will contribute in a variety of ways because "each of us is born somewhat different from the others, one more apt for one task, one for another." Therefore the healthy city will include specialists in various occupations such as farming, carpentry, metalwork, and provision of the markets needed for distributing the products of the various crafts. The farmer will want to sell grain in order to buy shoes, and the cobbler will want to sell shoes in order to buy grain. So that the cobbler does not have to sit around all day waiting for a farmer to show up and vice versa, the merchant will make a market that is available when needed. The existence of a market will also facilitate multiparty chains of exchange, as when the cobbler wants platters and the platter maker wants grain and the farmer wants a new roof and so on. Just as the contribution of the farmer requires expertise about when to sow and when to reap, the merchants' contribution requires expertise about such things as how much grain and how many pairs of

\footnotetext{
12 This "fevered" city discussed in the later books of the Republic has regularly but mistakenly been presented as what Socrates is advocating, despite the fact that Socrates states explicitly that

"...to me the true city is that which we described, like a healthy individual. However, if you wish, let us also observe the feverish city. " [II.372e]
} 
sandals to keep in stock. Like the farmers and the cobblers, the merchants should be able to earn their living by their work in their specialty, but exploitation or profiteering by merchants would be regarded as being just as much a harm to the whole community as it would be for farmers to destroy the land by overplanting for quick profit without regard to damage to the soil.

Society had, of course, become vastly more complex by the time Khurana published his 2007 history of U.S. business education, From Higher Aims to Hired Hands. ${ }^{13}$ However, Khurana shows that business education as part of the university began in the U.S. in the late nineteenth century with the intention of producing graduates who would play essentially the same role described by Plato and Hamilton, namely serving as what Khurana calls "stewards of society's economic resources."

Khurana begins his history of business education in the universities by noting the emergence of a major new occupation, namely management, during and following the Civil War as companies, primarily in the North, grew enormously in size and scope. The telegraph, typewriter, telephone and railroads brought a major leap in the possible size and speed of business, a leap as huge for the nineteenth century as electronic communication has been for today. In this context, there were those who hoped the new managers would defuse the tensions between owners and the other major new group produced by industrialization, the urban wage laborers, who were flocking to industrial cities from U.S. farms and from Europe.

To become technically competent, managers would need to learn how to arrange assembly lines, order raw materials, ship products, staff offices, keep records, etc. These technical needs make it unsurprising that the earliest managers emerged from among the engineers who built the factories and railroads and participated in the great expansions in communications that made huge operations possible.

Technological developments, however, cannot eliminate questions of social goals and values. Khurana reports that university-based higher education for managers, which began with the Wharton School in 1881, arose from

the efforts of a vanguard of institutional entrepreneurs, both academics and managers, who saw the need for creating a managerial class that would run America's large corporations in a way that served the broader interests of society rather than the narrowly defined ones of capital and labor. [4, bold italics added]

\footnotetext{
$\overline{13}$ Khurana's book has received multiple awards, including the 2007 Association of American Publishers Award for Best Professional/ Scholarly Publishing Book in Business, Finance and Management, and the 2008 American Sociological Association's Max Weber Best Book Award.
}

Khurana reports that this vanguard intended the university business school to produce "professionals" comparable to the products of medical and legal education. Khurana reviews the extensive literature on how "profession" should be defined, and he decides upon the definition offered by

Everett C. Hughes, a scholar of the modern occupational structure, who described the status of professions in American society as the result of a type of social compact: professions are given extraordinary privilege in exchange for their contributions to the enhancement of social order." 14

The "privilege" granted to business-the counterpart of the monopoly on medical and legal practice granted to licensed doctors and lawyers-was the corporate form, with its ability to amass more capital than a single individual generally could and its privilege of "limited liability," the protection of individual investors from loss of any money beyond what they had invested in the firm.

Using the word "profession" in this prosocial way that links it to professions such as medicine and law, Khurana states the project of his book as follows:

The history of the university-based business school is thus framed in these pages as a professionalization project undertaken, transformed, and finally abandoned over a period stretching from the founding of the Wharton School at the University of Pennsylvania in 1881 up to the present. [7]

We will look at Khurana's account of the abandonment of this project as we consider how today's trustworthy people of business could revive it.

\section{An Agenda for Marginalizing Caveat emptor Gamesterism: Reorienting MBA Education and Establishing Licensing for High Level Executives}

Society needs MBA programs to do what the MD and JD and other professional certifications are meant to do, namely train skilled, prosocial, responsible practitioners while being uncongenial to or too difficult for incipient charlatans or-in the case of corporate business-incipient caveat emptor gamesters, CEGs. The corporate structure has become too powerful for our trustworthy people of business to allow it to continue to be so often exploited by CEGs for their own excitement and personal wealth.

If enough faculty and supporters of MBA programs will decide to renew the nineteenth-century "professionalization

\footnotetext{
${ }^{14}$ P. 11, with footnote to Everett C. Hughes. "Professions." In The Professions in America, ed. Kenneth S. Lynn. Boston: Houghton Mifflin, 1963.
} 
project" and reorient the MBA toward stewardship, there would surely be enough insight, influence and skill among them to develop a course of study that would attract and prepare potential stewards while simultaneously deflecting potential CEGs. Reorienting the MBA would not require any action by national or state governments or by currently dominant business organizations such as the U.S. Chamber of Commerce. It is something the trustworthy practitioners and teachers of business could bring about simply by working together with the best MBA programs, i.e., the programs most interested in graduating stewards and therefore most interested in implementing a demanding course of study designed to attract potential stewards and deflect potential CEGs.

As trustworthy teachers and practitioners of business consider elements for a reoriented MBA course of study, two things that I have found in my own undergraduate business course to be effective in differentiating potential stewards from potential CEGs are substantial study of corporate history and substantial experience as an intern or employee in an organization that does not have profit maximization as a primary goal.

The value of internships is already widely recognized today in business education as in other disciplines, but to help MBA programs be attractive to potential stewards and unattractive to potential CEGs, internships need to be with prosocial organizations. Setting up prosocial internships would be greatly aided by the fact that today's "social entrepreneurs" have created a growing number of prosocial for-profit companies that already model the goal of stewardship, as do many prosocial non-profit organizations.

While the value of internships is recognized in MBA programs, the value of the study of history is not. This neglect is damaging, because well-taught history involves entering into the thinking and values of people of different times and circumstances in order to be able to reflect on one's own thinking and values. Students low in empathy and reflectiveness and strongly oriented toward games are likely to find historical study difficult and unrewarding, since history cannot be deeply understood by "gamethink" any more than by simply memorizing dates. Potential stewards, on the other hand, tend to find historical study illuminating and worthwhile.

History courses are particularly likely to be unattractive to students who accept the view that companies should focus on moving with speed in order to leave their competitors in the dust, even if that means distributing something whose safety has not been fully researched. Such students are at risk of agreeing with Jack Welch that executives should "ponder less and do more." Welch writes that

strategy is a living, breathing, totally dynamic game. It's fun—and fast. And it's alive. Forget the scenario planning, year long studies, and hundred-plus-page reports. They're time-consuming and expensive, and you just don't need them.... If you want to win... ponder less and do more. (Welch 2005, p. 166)

The title of one airport book proclaims it's Not the BIG that eat the SMALL; it's the FAST that eat the SLOW. The authors write that the only difference between "speed" and "haste" is that "speed" has "a destination in mind." (Jennings and Haughton 2000, p. 9)

Prosocial internships and strong history courses could help screen potential CEGs out of MBA programs without taking on the problems of "character tests." Instead, the history and prosocial internship requirements would contribute to screening in the way that the need for rhythm in musical studies attracts some students and screens out others. Similarly, some medical schools are developing what has been called "a people skills test" to help screen out candidates who are unlikely to be sufficiently attuned to patients (Harris 2011). ${ }^{15}$ I have seen many college students drop plans for applying to law school or medical school when they find that they do not want to do or cannot do the type or level of work required.

Two historical topics that have appeared to me to differentiate potential CEGs from potential stewards among my own students are history of the corporate form in the U.S. from colonial times to the present and history of the MBA itself. Here is a sampling of materials that I have found effective for each, followed by additional recommendation of the licensing which is needed in addition to upgrading of the MBA curriculum.

\section{History of the Corporate Form in the U.S.}

An eye-opening beginning for the history of the corporate form in the U.S. has been pointing out that the reason corporations are not mentioned in the Constitution is not that they were unimportant but that this topic, like slavery, was too hot to handle and would have made it impossible for the 1787 Constitutional Convention to reach consensus. Because disagreement about corporations was so intense, the issue of corporations, like the issue of slavery, was left to the individual states.

What made the issue of corporations so fraught was memory of the favoritism shown by monarchs of Europe in granting the lucrative charters of incorporation. Favoritism was in turn exhibited by colonial governments, resulting, among other things, in a problematic proliferation of

\footnotetext{
${ }^{15}$ Harris writes that "Doctors save lives, but they can sometimes be insufferable know-it-alls who bully nurses and do not listen to patients. Medical schools have traditionally done little to screen out such flawed applicants or to train them to behave better, but that is changing."
} 
lucrative private banks and insurance companies. John Sloss Hobart, who in the $18^{\text {th }}$ century was a prominent high court justice in the state of New York, wrote that "All incorporations imply a privilege given to one order of citizens which others do not enjoy, and are so far destructive of that principle of equal liberty which should subsist in every community." 16

This debate about corporations was a part of wider debates about what sort of country people wanted the new United States to become. For example, Alexander Hamilton and others in favor of establishing a national bank wanted the U.S. to focus on becoming an international mercantile power, while Thomas Jefferson and others advocated a nation of independent yeoman farmers and artisans.

One of many expressions of popular concern about corporations was an 1801 protest by independent artisans against an effort by "several of New York City's wealthy merchants to form a joint-stock company that was capable of supplying enough bread for the entire city and that offered to hire the previously independent bakers." ${ }^{17}$ The protest included artisans from many crafts who came together to resist what they saw as a movement to "monopolize by degrees all profitable mechanical branches." The artisans "feared that once the 'monopolies' had reduced most artisans to wage laborers, they could then use their power to reduce wages so that 'the independent spirit, so distinguished at present in our mechanics, and so useful in republics, will be entirely annihilated.'”

The historian Gordon S. Wood has written that in the new United States,

Once the old [colonial] hierarchies disintegrated..., the new states' attempts to grant such corporate privileges to select individuals and groups immediately raised storms of protest. When in the Philadelphia [Constitutional] Convention James Madison proposed that the federal government be given the explicit power to grant charters of incorporation, the framers decided to finesse the issue by saying nothing in the Constitution about incorporations out of fear of arousing popular opposition to "mercantile monopolies.'.... Such franchises and privileged grants may have made sense in monarchies... [b]ut now that only the people ruled, these grants of corporate privileges seemed pernicious.... [Wood 1992, pp. 319-320]

\footnotetext{
16 Quoted in Hartog (1983).

17 "Note: Incorporating the Republic: The Corporation in Antebellum Political Culture." Harvard Law Review, June, 1989. Such notes are typically written by members of law review staffs and published anonymously.
}

Judge Spencer Roane of the Virginia Supreme Court ruled as follows in 1809 in Currie's Administrator vs. Mutual Assurance Society:

With respect to acts of incorporation, they ought never to be passed, but in consideration of services to be rendered to the public.... It may be often convenient for a set of associated individuals, to have the privileges of a corporation bestowed upon them; but if their object is merely private or selfish; if it is detrimental to, or not promotive of, the public good, they have no adequate claim upon the legislature for the privilege." (Roane 1809)

Despite popular opposition, however, those interested in expanding the powers of corporations for purposes of "private" gain continued their efforts. Through the courts and legislatures, they sought powers beyond those granted to corporations in the early U.S. to enable the pooling of capital needed for large projects for the public such as building a road, powers such as the ability of the corporation itself to be a party to a contract in the way individual people could ("corporate personhood") and "limited liability," the protection of investors from liability beyond the sum each had invested. Those interested in greater powers for corporations to make them better vehicles for private gain began to seek, for example, what was called "general" incorporation, as contrasted to the "special" incorporation to which profit-making corporations were limited. "Special" incorporation required a specification of a particular project and approval by a special act of a state legislature. "General" incorporation, by contrast, was granted to schools and churches without limiting them to a specific project, the goal being to protect their freedoms of religion and speech. Those in favor of allowing expanded powers to for-profit companies went to work, and through courts and legislatures, and thus out of the view of the large portion of the population that does not closely follow activities in those arenas, succeeded in obtaining the privilege of general incorporation. Similarly, forces supporting for-profit corporations brought about such things as the dropping of restrictions on the magnitude of profits. Khurana summarizes these developments as follows:

An increased rate of incorporations under 'general law' as opposed to 'special acts' of the legislature was the result of a series of Supreme Court rulings (beginning with its landmark decision in Dartmouth College v. Woodward in 1819 that found that corporations of all sorts possessed rights as private entities, so that state legislatures could not easily revoke their charters). As a result, legislatures began to loosen their restrictions on what corporations could do. For example, in 1830, the Massachusetts legislature eliminated the requirement 
that a corporation be engaged in public works [in order] to be given the status of limited liability. Connecticut did the same in 1837 . By 1850, many states were competing with one another to define corporate rights as broadly as possible, with New Jersey and Ohio (where Standard Oil exerted significant influence) offering some of the most liberal terms. (Khurrana 2007, p. 407)

As for-profit corporations accumulated greater powers and protections, concern about them also continued to grow. Abraham Lincoln, reflecting on the hugely accelerated industrialization of the North during the Civil War, wrote to Col. William F.Elkins in 1864 as follows:

We may congratulate ourselves that this cruel war is nearing its end.... but I see in the near future a crisis approaching that unnerves me and causes me to tremble for the safety of my country. As a result of the war, corporations have been enthroned and an era of corruption in high places will follow, and the money power of the country will endeavor to prolong its reign by working upon the prejudices of the people until all wealth is aggregated in a few hands and the Republic is destroyed. I feel at this moment more anxious for the safety of my country than ever before, even in the midst of war. (Lincoln 1864, p. 40)

Henry Adams wrote in 1870 in Britain's Westminster Review that

The belief is common in America that the day is at hand when corporations... after having created a system of quiet but irresistible corruption, will ultimately succeed in directing government itself. Under the American form of society, there is now no authority capable of effective resistance.... Nor is this danger confined to America alone. The corporation is in its nature a threat against the popular institutions which are spreading so rapidly over the whole world,... and unless some satisfactory solution of the problem can be reached, popular institutions may yet find their very existence endangered. (Adams 1870)

The U.S. Supreme Court in 1886, in the 14th Amendment case of Santa Clara County v. Southern Pacific Railroad, opened the way for a major extension of the privileges of corporations beyond being legal "persons" only in the sense of being entities capable of being a party to a contract or law suit. The 14th Amendment to the Constitution, the amendment promising "equal protection" of the laws, had been adopted just after the Civil War to guarantee the rights of the newly freed slaves, including the rights guaranteed under the Bill of Rights. The pro-corporation clerk drafting the Santa Clara opinion included corporations in the preface to the opinion in a way that expanded the understanding of corporations as "persons" to include them under the protections of the 14th Amendment along with the newly freed slaves. Pro-corporation groups quickly brought other suits citing Santa Clara as a precedent to lock in this expansion. ${ }^{18}$

Santa Clara's bringing of corporations within the protections of the 14th Amendment, and thus of the Bill of Rights, by piggy-backing on the newly freed slaves has received renewed attention recently in relation to the most recent dramatic expansion of corporate power, the 2010 Citizens United ruling by the Roberts Supreme Court. (Citizens United 2010) the ruling empowers for-profit corporations to do such things as spend unlimited amounts of money in support of candidates during an election on the grounds that corporations as "persons" are entitled to free speech under the Bill of Rights. In the 2012 Presidential election, the first in which corporations could spend unlimited sums, the Republican candidate, Mitt Romney, casually sliding from "persons" to "people," stated that "corporations are people." One response to this was "I'll believe corporations are people when they hang one in Texas."

In the Progressive Era of the late nineteenth and early twentieth century, the expansion of the legal powers and protections accumulated by for-profit corporations was reflected in a division within the business community that was already present at the Constitutional Convention and continues still today. Some in the business communityseized opportunities such as the Santa Clara case to expand the powers of the corporate form as a vehicle for increased personal power and wealth. Contrasting to this were what we have seen Khurana describe as

the efforts of a vanguard of institutional entrepreneurs, both academics and managers, who saw the need for creating a managerial class that would run

America's large corporations in a way that served the

broader interests of society rather than the narrowly defined ones of capital and labor. [4, bold italics added].

A reflection of this division was that in the Progressive period in which medicine and law not only upgraded professional education but also established licensing to make individual practitioners more accountable, business established professional education but not licensing. Instead, continuing aggrandizements of the corporate form made it easier for individual executives as well as the corporate entity to avoid public accountability.

Between Santa Clara and Citizens United, ongoing concern about corporations is illustrated by such things as

\footnotetext{
${ }^{18}$ For an excellent discussion of the Santa Clara case, see Horwitz (1985).
} 
the famous warning issued by Republican President Dwight Eisenhower in 1961 on his last day in office:

the acquisition of unwarranted influence, whether sought or unsought, by the military-industrial complex.. [carries]... the potential for the disastrous rise of misplaced power.... We must never let the weight of this combination endanger our liberties or democratic processes. (Eisenhower 1961. For additional comments on corporations by U.S. Presidents, see Beets 2011)

MBA students who had studied the evolution of the corporate form would be in a position to discuss whether there are ways to hold today's for-profit corporations to the prosocial role required of corporations at the beginning of U.S. history.

\section{History of the MBA}

The history of the MBA itself could be an organizing theme for a course looking at several topics society needs its corporate executives to be thoughtful about, such as mathematical modeling. Khurana's book From Higher Aims to Hired Hands could serve as a splendid course text. ${ }^{19}$ Like other good histories, Khurana's illuminates its topic by placing it in relationship to broader social trends, and at the same time, the book identifies significant actions taken by individual persons in particular circumstances. Recounting individual actions is an important part of what makes history illuminating, whereas individual actions are generally invisible to mathematical models. Discussion of such actions can encourage students to ask themselves about their own relationship to action. In addition, the project of working through Khurana's meticulously researched and reasoned book would help students who are potential stewards recognize the shallowness of texts such as "airport" books. At the same time, students who are potential CEGs are likely to find Khurana's text too difficult and/or frustrating, and that could help encourage them to drop the idea of pursuing an MBA.

Of the broader social trends noted in Khurana's book, three that would be especially worthwhile for today's MBA students to look at are the Progressive movement of the nineteenth and early twentieth centuries, the "management science" produced by the Second World War, and what can be referred to as "mathematicism."

In connection with Progressivism, students could look at seeds of it in the 1865 creation of the American

\footnotetext{
19 Khurana's valuable text is being noticed in other discussions of business education reform as well, see, for example, the 2010 issue on business education published by the British Journal of Management (Vol. 21, S1-S5].
}

Association for the Promotion of Social Science, which developed into the American Social Science Association (ASSA). The Association was created for the purpose of developing knowledge about society not simply to expand knowledge for its own sake but also to find ways to deal with the new and growing problems of industrialization and urbanization. These problems included pollution and sanitation issues and the plight of the new urban wage laborers that led workers to organize such groups as the Knights of Labor, formed in 1869. All of these are splendid topics for student papers or discussion groups.

Looking at Progressivism could also include a comparison of the professionalizing goals of the prosocial founders of business education with those of other prosocial groups in addition to medicine and law. For example, social work, which began as a profession in this same period, has retained its progressive ideals, with the result that it has today a professional code that would be very worth discussion by MBA students. The code is summarized in its own "Preamble" as follows, with elaborations of each of the six "core values" that are simply listed here: ${ }^{20}$

The mission of the social work profession is rooted in a set of core values.... embraced by social workers throughout the profession's history....:

Service

Social Justice

Dignity and worth of the person

Importance of human relationships

Integrity

Competence

The code of a more recently founded prosocial organization of professionals, the National Network of Public Health Institutes, founded in 2001, includes the following in its Preamble:

Public health is understood within these principles as what we, as a society, do collectively to assure the conditions for people to be healthy.

We affirm the World Health Organization's understanding of health as a state of complete physical, mental, and social well-being, and not merely the absence of disease or infirmity....

A key belief worth highlighting, and which underlies several of the Ethical Principles, is the interdependence of people. This interdependence is the essence of community. Public health not only seeks to assure the health of whole communities but also recognizes

\footnotetext{
${ }^{20}$ The full code of the National Association of Social Workers is available in Spanish and English at http://www.socialworkers. org/pubs/code/default.asp retrieved July 22012
} 
that the health of individuals is tied to their life in the community. $^{21}$

A code can be valuable if simply for the extensive deliberation required to formulate it. Once formulated, a code can be a valuable instrument for helping a field's prosocial practitioners remember the goals of their profession or recognize needed changes. The code should therefore be examined closely in the education preparing for entrance to the profession, and a licensing exam should include questions designed to show that the candidate understands and can articulate it. A code can be valuable in these ways without taking on the drawbacks of a signed oath, which CEGs could sign, even sign ostentatiously, without feeling actually bound by it, making the oath useless in shaping their behavior and discouraging to those who sign in good faith and see the oath's inability to curb CEGs.

Moving from the Progressive Era to World War II, MBA students could discuss Khurana's point that "because the war was being fought between the advanced industrial powers, it was in part a contest of organizational and managerial skill" [199]. He says in this connection that the war accustomed Americans to "features of a large-scale bureaucracy, with its defined authority structures, administrative rules, and predictable career paths" [200]. After the war, there was a continuation of "trends in management set in motion by the organizational demands of World War II" [206].

Khurana shows that the victory of the U.S. in the war's "contest of organizational and managerial skill" (including the emergence of the digital computer) shaped post-war thinking about "civilian" management. Just as the Civil War's new industrial-strength management, made possible by the typewriter-telephone-telegraph-railroad communications leaps, had led to a "belief that enlightened administration of large organizations, public and private, held the key to establishing a new social order on a scientific and rational footing" [43], so World War II produced a belief in the possibility of a "redefinition of business school curriculum and research on a rigorous, scientific basis as the primary mechanism through which a profession of management could be created" [271].

This post-World War II view that Khurana calls "managerialism" or "scientific management" rested on an idea that

there now finally existed [because of World War II] a 'management science' that could be taught....[T]he decision-making tools developed during the war, such as decision analysis and game theory, combined

\footnotetext{
21 The full Code is available at http://nnphi.org/uploads/media_ items/ph-code-of-ethics-booklet.original.pdf Accessed June 26, 2012.
}

with the theoretical insights from the behavioral sciences, constituted the basic elements of this new management science.... [which] could best be taught to students... through a rigorous immersion in quantitative analysis and concepts from decision theory. [271, bold italics added]

Just as it was railroad engineers who pioneered the emergence of "management" as part of industrialization after the Civil War, so the dramatic upsurge of digital computing in and after World War II produced the belief that "there now finally existed" a "management science," inspiring, among other things, today's "quants" in economics, a number of whom started off as physicists.

Studying this idea of a "management science... best taught...through quantitative analysis" would offer an opportunity for business students to consider a third and especially deep-rooted Western social trend, namely what we may call "mathematicism" in general. In the Western intellectual tradition there are recurring moments in which an advance in mathematics or logic has produced in some enthusiasts a belief that "there now finally existed" some formal tool that would enable humankind to bring all important knowledge together into one formal system. The Pythagoreans of Ancient Greece were thrilled by impressive discoveries such as the possibilities of modeling music geometrically - e.g., a string double the length of another string sounds an octave lower. They concluded that "there now finally existed" a universal key to knowledge and famously announced that "all is number." Galileo, thrilled by new advances such as the geometry of the lenses he used in his telescopes, wrote that "this grand book... the universe... stands continually open to our gaze, but it cannot be understood unless one first learns... the language in which it is written.... the language of mathematics (Galileo 1623). Leibniz, who independently invented the calculus at the same time as Newton, was inspired by his invention to a belief that it would eventually be possible to devise (although he never devised it) a system of notation to be called the "universal characteristic" that would allow even ethics to be mathematicized, so that instead of arguing in ethics, we would say like the physicists, "Come, let us calculate" (Leibniz 1685). A few decades later enthusiasm for the calculus combined with the development of statistics to inspire a belief that "there now finally existed" methods of mathematical modeling that could do for society what Newton's physics had done for the material world. This belief led to what first the French philosopher August Comte and then the Belgian statistician Adolphe Quetelet called "social physics," ancestor of such studies as today's “econometrics." (Quetelet 1835)

It is important for MBA students to understand that throughout history mathematicist rounds of "there now finally existed" have repeatedly shown their inherent 
limits. These limits are even deeper than straightforward blunders, even though blunders can do enormous damage. An example is the damage done to so many in the 2008 collapse because bond rating agencies failed to include in their models the possibility that housing prices might go down instead of always up, the possibility that there might be negative numbers their model did not take into account.

At least three sorts of limitation deeper than blunders are particularly important for business students to consider. One is that formal systems of mathematics and logic are "value neutral." That is, individual people who happen to be mathematicians or logicians, whether in economics or any "science," may, like everyone else, have opinions about questions of value, but these opinions cannot be derived from their formal model unless they are already present in the starting assumptions or premises. Business students need to reflect on this in order to be aware of value assumptions they may be making, so that they can ask themselves about the sources of their value assumptions or premises and on what grounds they might recommend them to others, since a system does not prove its own assumptions.

One accessible and historically important place to begin discussion of this value neutrality would be examination of the "is/ought" distinction made in the late eighteenth century by David Hume, one of the major early modern philosophers who worked to revise Western philosophy to fit the "Scientific Revolution" epitomized by Newton's mathematical physics. [Hume 1739 Bk. III, Part I, Sect. I] Hume's way of putting what is sometimes called the "fact-value distinction" was that "ought" statements cannot be deduced from "is" statements, and that the combination of direct observation and formal manipulation that constitutes natural science, what Hume called "reason," makes only "is" statements, not "ought" statements, or in other terms, makes only "descriptive" statements and not "normative" or "prescriptive" statements. Apart from the statements of natural science or "reason," all the rest of what Hume called "actions of the mind," including ethics and aesthetics, were said by him to come under not "reason" but "sentiment," an important eighteenth century concept vastly richer and more complex than the "emotion" to which Logical Positivists such as A. J. Ayer reduced it in their early twentieth-century neo-Humeanism, a reduction that itself can be another splendid paper topic for students. [Ayer 1936/46]

Hume's is/ought distinction can be illustrated by comparing the statement that "tobacco companies increase sales by advertising," an "is" statement shown by marketing research to be true, with the profoundly different statement that "tobacco companies ought to increase sales by marketing." There is continuing vigorous debate about the "fact/value" distinction, and MBA students would benefit from looking at that discussion.
A different sort of example of the inability of formal systems to generate value statements is offered by today's very appropriate excitement among scientists and science fans about evidence that the giant Hadron Collider has found the hypothesized sub-atomic particle called the $\mathrm{Hi}$ ggs Boson, long sought by physicists and astronomers. If it has been discovered, however, and if it eventually turns out, as basic science so often does, to have possibilities for practical applications, the discovery itself will not tell us what we "ought" to do about those possibilities, just as the discovery of how to split the atom did not tell us whether or not to make a bomb, or whether or not to drop our bomb once we had made it.

In addition to value neutrality, a second recurring issue in working with formal systems is how to deal with situations in which the formal model and the world do not match. One type of response can be called the "Procrustean bed" response, after the ancient king Procustus, who was said to deal with the quandary of a guest too tall for the bed by chopping down the guest's legs to fit. A historical example of requiring the world to fit one's theory rather than the other way around is Kepler's acceptance of the ancient assumption that the planetary orbits must be circular, an assumption which delayed for many years Kepler's realization that the orbits are actually elliptical.

An example from economics of mismatch between a formal theory and the world has been the problem of finding assumptions about humans that are both convenient for economic theories and actually true of humans. For this, business students could read the essay "Rational Fools" by the philosopher and Nobel Prize winning economist Sen (1977). Sen's essay begins with discussion of F. Y. Edgeworth's (1881) book, Mathematical Psychics: An Essay on the Application of Mathematics to the Moral Sciences:

Edgeworth asserted that "the first principle of Economics is that every agent is actuated only by selfinterest." This view of man has been a persistent one in economic models.... In this essay I would like to examine some of the problems that have arisen from this conception of human beings. I should mention that Edgeworth himself was quite aware that this socalled first principle of Economics was not a particularly realistic one. Indeed, he felt that "the concrete nineteenth century man is for the most part an impure egoist, a mixed utilitarian." This raises the interesting question as to why Edgeworth spent so much of his time and talent in developing a line of inquiry the first principle of which he believed to be false.

Another possible response when a model fails to fit the world is just to leave out the inconvenient aspects of the world. Economists call these omitted aspects "externalities," and the omission can happen either consciously or 
unconsciously. A major contribution by feminist economists in the 1980s in the "Second Wave" of the women's movement was to point out that neither "mainstream" neoclassical economic theory nor Marxian economic theory included a place for unpaid domestic labor, with the result that the huge portion of the world's work that is done in the home-and still primarily by women - was treated as being of no economic significance. Some economists tried to repair this embarrassing omission by seeking ways to quantify domestic labor in order to add it while leaving their basic model intact. But others, such as economist Julie Matthaei, are addressing the deeper gender assumptions reflected in currently dominant models. For example, the model known as "the sexual division of labor" has tended to involve an assumption that the "public" sphere of paid labor will be made up mostly of men, with women in the "private" sphere of unpaid labor. Economists such as Matthaei have begun developing models with more adequate approaches to gender, and business students could gain a greater understanding of modeling as well as of gender by looking at these more imaginative approaches (Matthaei 2001).

Sometimes an aspect of the world is consciously treated as an economic externality because the makers of a model find that aspect disadvantageous to include. For example, Jacob S. Hacker and Paul Pierson report as follows the objections of economist Joseph Stiglitz to treating environmental degradation as an externality:

[Stiglitz believes that] "our economy is being overwhelmed by politically engineered market advantages.... By this he [Stiglitz] means economic returns above normal market levels that are derived from favorable political treatment.... [This favorable treatment includes classifying some things as] 'negative externalities, or costs that economic producers impose on society for which they don't pay. The spectacular profits of the energy industry, for example, rely heavily on the failure of regulation to incorporate fully the social and economic costs associated with environmental degradation, including climate change (Hacker and Pierson 2012).

Finally, an experience of working with formal theories that has repeatedly frustrated enthusiasts of mathematicism is having the theory tie itself into a knot. Thus the ancient Greeks, despite their splendid achievements in geometry and logic, were left with "Zeno's Paradoxes." These included the "proof" that the tortoise could beat Achilles in a footrace if the tortoise were given a head start, however small, and kept moving. After all, Achilles would first have to run to where the tortoise started, but by the time he got there, the tortoise would have moved farther on... and on and on, until the tortoise crosses the finish line with Achilles ever closer but always still behind.

The failures of theories have continually inspired theory makers to try again, and that is fine and interesting and potentially fruitful, as long as there is no speedy ("it is the FAST that Eat the SLOW"), or distorted or self-serving application that injures people or the environment.

Bringing together consideration of mathematicism and of the dream of "management science" after World War II, Khurana provides the following capsule history of how the dream crashed in the Vietnam war:

By the late 1960s there was growing doubt about the claims and usefulness of management science. As Steven Sass notes...: 'Errors in modeling, measurement, or computation had led to serious blunders, and in some cases the results were unequivocally disastrous.' The mounting casualties in Vietnam, combined with the hubris shown by former Ford Motor Company Whiz Kid and Harvard Business School accounting professor Robert McNamara, eventually offered a 'nagging public symbol' of management science's human cost and seemed to indict the notion that cold, rational calculus was productive of good judgment. [286]

A business class discussing this topic could watch Errol Morris's 2003 documentary about McNamara, The Fog of War, and discuss McNamara's chastened conclusion that war "is so complex it's beyond the ability of the human mind to comprehend all the variables." (Morris's 2003, p.18 of a 19 page printout) Trying "to comprehend all the variables" in McNamara's mathmaticist sense is the approach of a computer programmer, not of a historian or poet. But the evidently well intentioned McNamara seems to have had only mathematicist thinking to draw upon. At this point it would be important for business students to discuss what ways of thinking and approaches to planning and decision making they conclude might be needed when computer modeling and other forms of mathematicism prove inadequate or misleading.

After tracing the emergence and decline of "management science" as a foundation for business education, Khurana moves on to discuss its worrisome successor, which he refers to as "the 'leadership' nostrum" [352], "nostrum" being defined by the Oxford English Dictionary as "a quack remedy or patent medicine." "Leadership studies" is characterized by Khurana as another episode in a problematic strand present in the business education movement since its beginning. That strand has been the desire of some to appropriate the prestige of being part of a university without demanding the combination of complex thinking and commitment to social benefit that is essential to marginalizing charlatans in any profession. An attempt 
to appropriate the university in this way is, of course, fully compatible with caveat emptor gamesterism.

Khurana reports that "academic concern with the subject of leadership began [in the social sciences] in 1945," but he concludes in his 2007 book that

Leadership as a body of knowledge, after decades of scholarly attention... remains without either a widely accepted theoretical framework or a cumulative empirical understanding leading to a usable body of knowledge. Moreover, the probability that leadership studies will make significant strides in developing a fundamental knowledge base is fairly low. The reality is that inside universities and research-based business schools, leadership research has relatively low status. In elite business schools, for example, there are no 'leadership' departments.... Within the Academy of Management, the largest professional association for business school scholars, leadership is not even recognized as a distinct interest group or subfield.... [357]

Why business schools nonetheless turned toward "leadership" is explained by Khurana as follows:

By the beginning of the 1990s, business schoolsparticularly those elite schools that had staked their reputations on academic superiority [in the period in which faculty like McNamara of the Harvard Business School had been proclaiming management science]_faced a full-blown crisis of identity and purpose. It was no longer possible for business schools to tout a mission of educating managers according to the canons of postwar (i.e., post World War II) managerialism, for traditional managers had been successfully portrayed by the takeover artists and shareholder activists of the 1970 and 1980s [and others]... as incompetent at best, and venal and untrustworthy at worst.

Moreover, increasing numbers of students at the most prestigious schools now shunned traditional management careers altogether in favor of fields like consulting and investment banking [to which the advent of computers had given increased vitality for better or for worse]. Faculty at the elite business schools were thus educating fewer future managers, which left them increasingly ambivalent and uncertain about what they were educating students for.... It was thus in a pervasive atmosphere of drift and uncertainty that business schools turned to the notion of leadership as a way to define their identity and mission....

In the early 1990s, for example, Harvard Business School formally shifted its focus from its traditional concern with general management, issuing a new mission statement that described its purpose as 'to educate leaders who make a difference in the world.' [352-55]

The economic collapse of 2008, involving many MBAs from prestigious universities, certainly "made a difference." By contrast, an MBA program based on stewardship of society's resources would require study and commitment every bit as demanding as that of medicine or law or any other graduate study in order to address such questions as what an environmentally sustainable economy could look like, or how an economy could free itself from dependence on trash-producing consumerism and on weapons manufacture carried far beyond the actual needs of defense, or how a society claiming to be an equal opportunity democracy can eliminate such contradictions as racial disparities in healthcare or failure to provide to all children the good schools necessary for full citizenship. Education for such stewardship, as McNamara discovered in The Fog of War, would require study of much more than mathematical modeling.

\section{Licensing}

The corporate form has over time become too powerful and too free from limitations to be left unprotected from CEGs, and licensing would make it harder for corporate officers to evade individual responsibility if they exploit today's corporate form to benefit themselves rather than society. Therefore, to be sure that people who reach high level corporate positions without an MBA have passed through screening similar to the MBA, and to help hold MBA programs to high standards, society needs its trustworthy people of business to design and establish licensing correlated to the MBA as medical and legal licensing is correlated to professional education in those fields. In addition to an employment history and to performance on exams, materials to be provided by candidates could include testimonies to the candidate's competence and commitment to prosocial stewardship written by appropriate recommenders. What corporate positions would require a license could be defined by such existing criteria as size of budget controlled, extent of supervision of subordinate departments, or powers of determining policy or hiring/firing managers.

\section{Conclusion}

The United States needs its trustworthy teachers and practitioners of business to take steps to protect high level corporate positions from caveat emptor gamesters and to attract stewards. A major step toward both of these goals could be developing an MBA curriculum that would be 
attractive to potential stewards and unattractive to potential CEGs. Promising elements of such a curriculum would be demanding history courses and internships with prosocial businesses or non-profit organizations. A closely related step would be establishment of correlated licensing for high level corporate positions, whether as managers or directors.

After reorientation of the MBA and establishment of licensing, there would still be questions of what greater provisions society can make to help all children and especially low reactive/uninhibited children develop into prosocial adults, of what alternative provisions society can make for adults who do become caveat emptor gamesters, and of how the corporate structure itself should be reformed. But high level executives and directors who were stewards would help society address these questions.

It would be possible for reform to begin quickly, since it would not require either government action or massive new funding. Today's trustworthy people of business are a group that includes individuals from our oldest corporations all the way across to today's newest "social entrepreneurs," as well as many faculty teaching business. If some among these many trustworthy people of business will choose to do so, they can start the U.S., and indeed the world, moving toward a time of greater safety and a more just, healthful and environmentally sound management of economic resources, a time when corporations are more like the hospitals and universities in which prosocial professionals practice their callings. "Let the buyer beware" could then come to seem as surprising on the wall of a bank or other corporation as "let the patient beware" would seem today on the wall of a physician.

Acknowledgments I am very grateful to the following for commenting on drafts, in some cases more than once: Jonathan M. Cheek, Bell Gale Chevigny, Paul G. Chevigny, Frederick R. Chromey, T. Walter Herbert, Julie R. Horvath, Francis G. Hutchins, the late Miranda C. Marvin, Mary L. Shanley, Kenneth P. Winkler, James P. Womack, and two anonymous reviewers for the Journal ofBusiness Ethics. Remaining flaws are almost certain to be places in which I failed to follow their advice.

\section{References}

Acharya, V., \& Schnable, P. (2009). How banks played the leverage game. In V. Acharya \& M. Richardson (Eds.), Restoring financial stability: How to repair a failed system (pp. 83-101). Hoboken, NJ: Wiley.

Adams H. (1870). The New York gold conspiracy. Westminster Review, 94 O.S., 38 N.S., 411-436.

Allard, K. (2004). Business as war: Battling for competitive advantage. Hoboken, NJ: Wiley.

Anonymous. (1989). Incorporating the republic: The corporation in antebellum political culture. Harvard Law Review, 102(8), 1883-1903.
Ayer, A. J. (1936, revised 1946). Language truth and logic. London: Victor Gollancz Ltd.

Beets, S. D. (2011). Crucial events in the ethics of U.S. corporation history. Journal of Business Ethics, 102(2), 193-219.

Boddy, C. R. (2011). The corporate psychopaths theory of the global financial crisis. Journal of Business Ethics, 102(2), 255-259.

Boudreau, J. W., Boswell, W. R., \& Judge, T. A. (2001). Effects of personality on executive career success in the United States and Europe. Journal of Vocational Behavior, 58(1), 53-81.

Citizens United v. Federal Election Commission, 558 U.S. 50 (2010).

Costa, P. T., Jr., \& McCrae, R. R. (1988). Personality in adulthood: A six-year longitudinal study of self-reports and spouse ratings on the NEO Personality Inventory. Journal of Personality and Social Psychology, 54, 853-863.

Digman, J. M. (1989). Five robust trait dimensions: Development, stability, and utility. Journal of Personality, 57, 195-214.

Edgeworth, F. Y. (1881). Mathematical psychics. New York: Oxford University Press (Reprint 2003).

Edsall, T. B. (2012, September 16). Is poverty a kind of Robbery. New York Times.

EIko K. (2009). Touchdown: Achieving your greatness on the playing field of business (and Life). Upper Saddle River, NJ: FT Press of Pearson Education Inc.

Eisenhower, D. D. (1961, January 17). Farewell radio and television address to the American people.

Enrich, D. (2012). Transcript of the PBS Newshour, July 6, 2012. Retrieved July 7, 2012, from http://www.pbs.org/newshour/bb/ business/july-dec12/bank_07-06.html.

Ferguson, C. (2010). Inside job. Representational Pictures, Sony Pictures Classics.

Galilei, G. (1623/1960). Il Saggiatore (The Assayer) (D. Stillman \& C. D. O'Malley. The Controversy on the Comets of 1618, English Trans.). Philadelphia: University of Pennsylvania Press.

Goldberg, L. R. (1990). An alternative "description of personality" : The Big-Five factor structure. Journal of Personality and Social Psychology, 59, 1216-1229.

Hacker, J. S., \& Pierson, P. (2012, September 27). What Krugman and Stiglitz can tell us (Vol. LIX, No. 14, pp. 55-58). New York: New York Review of Book.

Hamilton, W. (1931). The ancient Maxim Caveat emptor. Yale Law Journal, 40(8), 1133-1187.

Harris, G. (2011, July 10). New for Aspiring Doctors, the People Skills Test. New York Times.

Hartog, H. (1983). Public property and private power. Chapel Hill: University of North Carolina Press.

Hawley, P. H. (2003). Prosocial and coercive configurations of resource control in early adolescence: A Case for the well-adapted Machiavellian. Merrill-Palmer Quarterly, 49(3), 279-309.

Hogan, J., \& Ones, D. S. (1997). Conscientiousness and integrity at work. In R. Hogan, J. Johnson, \& S. Briggs (Eds.), Handbook of personality psychology (pp. 849-870). San Diego: Academic Press.

Horwitz, M. J. (1985). Santa Clara revisited. West Virginia Law Review, 88, 173-224.

Hume, D. (1739). A treatise of human nature (Bk. III, Part I, Sect. I). London: John Noon.

James, W. (1906). The moral equivalent of war. Introduction by Jon Roland. Retrieved July 2, from, 2012 http://www.constitution. org/wj/meow.htm.

Jennings, J., \& Haughton, L. (2000). It's not the BIG that eat the SMALL...it's the FAST that eat the SLOW. New York: Harper Business.

Kagan, J. (1997). Galen's prophecy. Boulder, CO: Westview Press.

Kagan, J. (2008). The biological contributions to temperaments and emotions. European Journal of Developmental Science, 2(1/2), $38-51$. 
Khurana, R. (2007). From Higher aims to hired hands: The social transformation of American business schools and the unfulfilled promise of management as a profession. Princeton, NJ: Princeton University Press.

Khurana, R. (2011, April 17). Why look down on a business degree. New York Times.

Kowert, P. A., \& Hermann, Margaret. G. (1997). Who takes risks? Daring and caution in foreign policy making. Journal of Conflict Resolution, 41(5), 611-637.

Krugman, P. (2012, January 8/9). America's unlevel field. New York Times.

Lafley, A. G., \& Charan, R. (2008). The game-changer: how every leader can drive everyday innovation. New York, NY: Crown Business imprint of Random House.

Leibniz, G. W. (1685/1951). The art of discovery. In P. P. Wiener (Ed.), Leibniz: Selections (p. 51). New York: Scribner.

Lincoln, A. (1864/1950). Letter to Col. W. F. Elkins, Nov. 21, 1864. In A. H. Shaw. The Lincoln Encyclopedia. New York, NY: Macmillan, p. 40.

Matthaei, J. (2001). Healing ourselves, healing our economy: paid work, unpaid work, and the next stage of feminist economic transformation. Review of Radical Political Economics, 33, 461-494.

McCabe, D. L., Butterfield, K. D., \& Treviño, L. K. (2006). Academic dishonesty in graduate business programs: Prevalence, causes, and proposed action. Academy of Management Learning and Education, 5, 294-305. September, 2006.

Morgenson, G. (2012, July 7). The british, at least, are getting tough. New York Times. Retrieved July 8, 2012.

Morris, E. (2003). The fog of war: Eleven lessons from the life of $R$. S. McNamara. Sony Pictures Classics. Retrieved July 3, 2012, from Transcript at http://www.errolmorris.com/film/fow_transcript.html.

National Network of Public Health Institutes. (2001). Code of Ethics. The full Code is available at http://nnphi.org/uploads/media items/ph-code-of-ethics-booklet.original.pdf. Accessed June 26, 2012.

Nicholson, N., Stone, E., Fenton-O'Creevy, M., \& Willman, P. (2005). Personality and domain-specific risk taking. Journal of Risk Research, 8(2), 157-176.

Nocera, J. (2011, April 5). Who could blame G.E.? New York Times.

Paulhus, D. L., \& Williams, K. M. (2002). The dark triad of personality: Narcissism, machiavellianism, and psychopathy. Journal of Research in Personality, 36(6), 556-563.
Plato (1997a). Republic. Trans. G.M.A. Grube and C.D.C. Reeve. In J. M. Cooper (Ed.), Complete Works of Plato (pp. 971-1223). Indianapolis, Indiana: Hackett Publishing Co.

Plato (1997b). Statesman. Trans. C. 1. Rowe. In J. M. Cooper (Ed.), Complete Works of Plato (pp. 294-358). Indianapolis, Indiana: Hackett Publishing Co.

Poulin, F., \& Michel, M. B. (2000). The role of proactive and reactive aggression in the formation and development of boys' friendships. Developmental Psychology, 36(2), 233-240.

Quetelet, A. (1835). Sur l'homme, et le développement de ses facultés. Translated in 1842 as A Treatise on Man and the Development of His Faculties. [Facsimile edition of the English translation with an introduction by Solomon Diamond: Scholars' Facsimiles \& Reprints, 1969].

Roane, Spencer. (1809). Currie's administrator v. Mutual assurance, 14 Va. 315, 347. Retrieved July 3, 2012, from http://www. houseofrussell.com/legalhistory/alh/docs/currie.html.

Roland, J. (2000). Introduction to William James's moral equivalent of war. Retrieved July 2, 2012, from http://www.constitution. org/wj/meow_intro.htm.

Rothbart, M. K., \& Bates, J. E. (1998). Temperament. In W. Damon (Series Ed.), \& N. Eisenberg (Vol. Ed.), Handbook of child psychology: Social, emotional and personality development, (5th ed., Vol. 3, pp. 105-176). New York: Wiley.

Santa Clara County v. Southern Pacific Railroad Company, 118 U.S. 394. (1886).

Sawhill, I. V., \& Morton, J. E. (2007). Economic Mobility in America: Is the American dream alive and well? Economic mobility project of the pew charitable trusts. Washington, PA.

Schwartz, C. E., et al. (2010). Structural differences in adult orbital and ventromedial prefrontal cortex are predicted by 4-month infant temperament. Archives of General Psychiatry, 67(1), $78-84$.

Sen, A. (1977). Rational fools. Philosophy \& Public Affairs, 6(4), 317-344.

Vey, P. C. (2009, March 9). Cartoon. New Yorker.

Welch, J. (2005). Winning. New York, NY: Harper Business.

Wood, G. S. (1992). The radicalism of the American revolution. New York: Alfred A. Knopf.

World Health Organization. (1990). International statistical classification of diseases and related health problems (ICD-10). 